Ecology

\title{
Cloud forests on rock outcrop and volcanic soil differ in indicator tree species in Veracruz, Mexico
}

\author{
Los bosques mesófilos en afloramiento rocoso y suelo volcánico varían en especies arbóreas \\ indicadoras en Veracruz, México \\ Guadalupe Williams-Linera*, Quetzalli Vizcaíno-Bravo \\ Red de Ecología Funcional, Instituto de Ecología, A.C., Carretera antigua a Coatepec Núm. 351, 91070 Xalapa, Veracruz, Mexico
}

Received 7 April 2016; accepted 4 August 2016

Available online 16 November 2016

\begin{abstract}
The tropical montane cloud forest (TMCF) of central Veracruz, Mexico, predominantly grows on volcanic substrate from the Quaternary (2-0.08 Mya), but in very small areas it grows on shallow soils over limestone rock outcrops from the Cretaceous (90 Mya). Our objective was to contrast the vegetation structure and tree species composition of forest communities growing on rock outcrops (FOR) with nearby forests on prevalent volcanic soil (FOV). Results show that species richness and vegetation structure were similar between FOR and FOV. However, a clear difference was revealed by indicator species analysis (ISA), and multinomial classification model (CLAM). ISA and CLAM, respectively, identified 14 indicators and 13 specialists in FOR, whereas, they identified 7 indicators and 14 specialists in FOV. Some FOR indicators were Cercis canadensis, Clusia guatemalensis, Garrya laurifolia, Ostrya virginiana and Quercus pinnativenulosa. Some FOV indicators were Carpinus tropicalis, Clethra macrophylla, Liquidambar styraciflua and Quercus xalapensis; these species are also common in several Mexican TMCF. Our study demonstrates that the tree community on rock outcrops differs from the surrounding forest on volcanic soils; this is of particular interest because of its different species assemblage and contribution to the high beta diversity of the region.

(C) 2016 Universidad Nacional Autónoma de México, Instituto de Biología. This is an open access article under the CC BY-NC-ND license (http://creativecommons.org/licenses/by-nc-nd/4.0/).
\end{abstract}

Keywords: Cloud forest; Limestone; Rare trees; Rock outcrops; Tree diversity; Vegetation structure; Volcanic soils

\section{Resumen}

El bosque mesófilo de montaña del centro de Veracruz, México, crece predominantemente en sustrato volcánico del Cuaternario (2-0.08 Ma), pero en áreas muy pequeñas crece en suelo poco profundo sobre afloramientos de roca caliza del Cretácico ( 90 Ma). El objetivo fue contrastar la estructura de la vegetación y la composición de especies arbóreas de comunidades en afloramientos rocosos (AR) con bosques cercanos en suelo volcánico (SV). Encontramos que la riqueza de especies y la estructura de la vegetación fueron similares entre AR y SV. Sin embargo, el análisis de especies indicadoras (ISA) y el modelo de clasificación multinomial (CLAM) revelaron una diferencia clara. ISA y CLAM, respectivamente, identificaron 14 especies indicadoras y 13 especialistas en AR, e identificaron 7 indicadoras y 14 especialistas en SV. Algunas especies indicadoras AR fueron: Cercis canadensis, Clusia guatemalensis, Garrya laurifolia, Ostrya virginiana, Quercus pinnativenulosa. Algunas especies indicadoras de SV fueron: Carpinus tropicalis, Clethra macrophylla, Liquidambar styraciflua y Quercus xalapensis; estas especies también son comunes en varios bosques mesófilos mexicanos. Se concluye que la comunidad de árboles en afloramientos rocosos difiere del bosque circundante en suelo volcánico. Estas diferencias en el ensamblaje de especies son de particular interés debido a que contribuyen a la alta diversidad beta regional. (C) 2016 Universidad Nacional Autónoma de México, Instituto de Biología. Este es un artículo Open Access bajo la licencia CC BY-NC-ND (http://creativecommons.org/licenses/by-nc-nd/4.0/).

Palabras clave: Bosque de niebla; Suelo calizo; Árboles raros; Afloramientos rocosos; Diversidad de árboles; Estructura de la vegetación; Suelos volcánicos

\footnotetext{
* Corresponding author.

E-mail address: guadalupe.williams@inecol.mx (G. Williams-Linera).

Peer Review under the responsibility of Universidad Nacional Autónoma de México.
} 


\section{Introduction}

Forest communities on rock outcrops have a distinctive floristic composition and physiognomy with respect to that of the surrounding forests. Outcrops with different substrates have been recognized worldwide as providing important habitats for biodiversity conservation, particularly for endemic and rare species (Aukema, Carlo, \& Collazo, 2007; Cantero et al., 2014; Gallardo-Hernández, Velázquez, \& Asbjornsen, 2008; Pérez-García \& Meave, 2004; Pérez-García, Sevilha, Meave, \& Scariot, 2009; Rivera, Zimmerman, \& Aide, 2000; Wiser $\&$ Buxton, 2009). Some differential trends have also been reported in vegetation structure and species composition on outcrops compared to those of nearby forests on deeper soils (Brewer, Rejmánek, Webb, \& Fine, 2003; Gallardo-Hernández et al., 2008; Sawada et al., 2015; Tang, Lü, Yin, \& Qi, 2011). In the tropics, in Mt. Kinabalu, Borneo, basal area and stem density differed among geological substrates but were similar among the topographical units of each substrate, indicating that the effects of geological substrate were generally stronger than those of topography (Sawada et al., 2015). In Xishuangbanna, China, the limestone forest had lower species diversity than other tropical forests in the area and differed in floristic composition and structure (Tang et al., 2011). In Chimalapas, Oaxaca, Mexico, the tropical montane cloud forest differed in woody plant composition but not in vegetation structure between communities growing on metamorphic rocks and sedimentary geological substrates forming a karst topography with rock outcrops (Gallardo-Hernández et al., 2008).

Tropical montane cloud forest (TMCF) is very heterogeneous and exhibits remarkable turnover in tree species assemblages across the landscape, with great natural diversity in its vegetation structure due to the variety of microhabitats and the elevation gradient over which it grows. Climate, topography, geology and substrate all contribute to the enormous biodiversity of this forest type (Bruijnzeel, Kappelle, Mulligan, \& Scatena, 2010; Churchill, Balslev, Forero, \& Luteyn, 1995; Williams-Linera, 2002; Williams-Linera, Toledo-Garibaldi, \& Gallardo-Hernández, 2013). In Mexico, TMCF is the most diverse vegetation type per unit area and although it covers less than $1 \%$ of the national territory, it accounts for $10 \%$ of plant diversity. One reason for the high diversity of TMCF is the mixing of Holartic and Neotropical biogeographic elements, and a high degree (30-35\%) of endemism (Rzedowski, 1996; Sánchez-Ramos \& Dirzo, 2014). Forest canopy trees primarily belong to Holartic taxa also common in the eastern deciduous forests of the United States, while subcanopy and understory vegetation are dominated by tropical genera, taxa common in the Andean forests of South America, and even a high number of taxa shared with eastern Asia (Rzedowski, 1996).

In central Veracruz, Mexico, the TMCF region is characterized by irregular topography, formed by hills and plateaus that are dissected by deep gorges. The morphology and prominent slopes in the region are mostly controlled by the volcanic chain formed by the Cofre de Perote Volcano. The Quaternary volcanic deposits are 0.08 to 2 million years old (Rodríguez, Morales-Barrera, Layer, \& González-Mercado, 2010). Isolated rock outcrops are uncommon in this region, and are part of a prevolcanic floor from the Late Mesozoic (Cretaceous, ca. $90 \mathrm{Ma}$ BP). In a few places on the cloud forest belt, these rock outcrops are quite exposed and form small, elongated mountain ranges oriented in a NW-SE direction; this carbonate sedimentary substrate is dominated by limestone with minor shale intercalations (Rodríguez et al., 2010).

Most of our current knowledge of Mexican TMCF comes from studies carried out on plant communities growing on soils of volcanic origin (Muñoz-Villers et al., 2012; Rossignol, 1987; Williams-Linera, 2002). For the present study, within the TMCF region, forest remnants on limestone outcrops were identified, and we asked whether forest on isolated limestone rock outcrops differed in its tree species composition and vegetation structure from the nearby forests growing on the most common geological substrate (volcanic soils). Our working hypothesis was that forest fragments growing on limestone rock outcrops would differ in their tree species composition and structure from forest remnants on volcanic soils. We based this hypothesis on the expectation that the tree species assemblage encountered in a particular habitat will reflect geological substrate and topography. We further expect that, if this is the case, there will be a subset of tree species that differed from the tree species pool of the TMCF developed on volcanic soils in central Veracruz.

\section{Materials and methods}

This study was conducted in central Veracruz, Mexico $\quad\left(19^{\circ} 30^{\prime} 13.12^{\prime \prime}-19^{\circ} 29^{\prime} 35.56^{\prime \prime} \mathrm{N} ; \quad 96^{\circ} 57^{\prime} 28.14^{\prime \prime}\right.$ $96^{\circ} 58^{\prime} 28.65^{\prime \prime} \mathrm{W}$; elevation 1,250-1,550 $\mathrm{m}$ asl) within the Trans-Mexican Volcanic Belt on the eastern slopes of the Cofre de Perote Volcano. The climate is mild and humid throughout the year with 3 seasons: a cool season from November to March, a short dry-warm season in April-May, and a wet warm season from June to October. At lower and higher elevation sites, mean annual precipitation values are 1,500 and $2,000 \mathrm{~mm}$, and mean annual temperature decreases from $19^{\circ} \mathrm{C}$ to $17^{\circ} \mathrm{C}$ (Williams-Linera, 2002; Williams-Linera et al., 2013). The main vegetation type is tropical montane cloud forest (Williams-Linera et al., 2013). The soils are predominantly on volcanic substrate across $>95 \%$ of the region (Inegi, 2010; Rossignol, 1987).

In this area, some sites are located on limestone rock prominences with abrupt slopes. The rock outcrops are in a small area ca. $5 \mathrm{~km}$ long between the towns of Xalapa and Coatepec (Fig. 1). Volcanic soils are deep (ca. 2.5 m) (Muñoz-Villers et al., 2012), well drained and with abundant organic matter, and the soil on the outcrops is shallow and rocky.

The study sites on rock outcrops were selected by examining geological maps from INEGI (2010; E14-B27 and E14-B37), images in Google Earth to locate hilltops with forest remnants, and ground verification of the entire surface on pre-volcanic limestone. With the help of a local guide, we visited all of the sites that still had forest on the hilltop. We found 8 and selected 4 sites based on the following criteria: (1) the forest was on a limestone rock outcrop, (2) cover $>1$ ha of forest at the relatively 


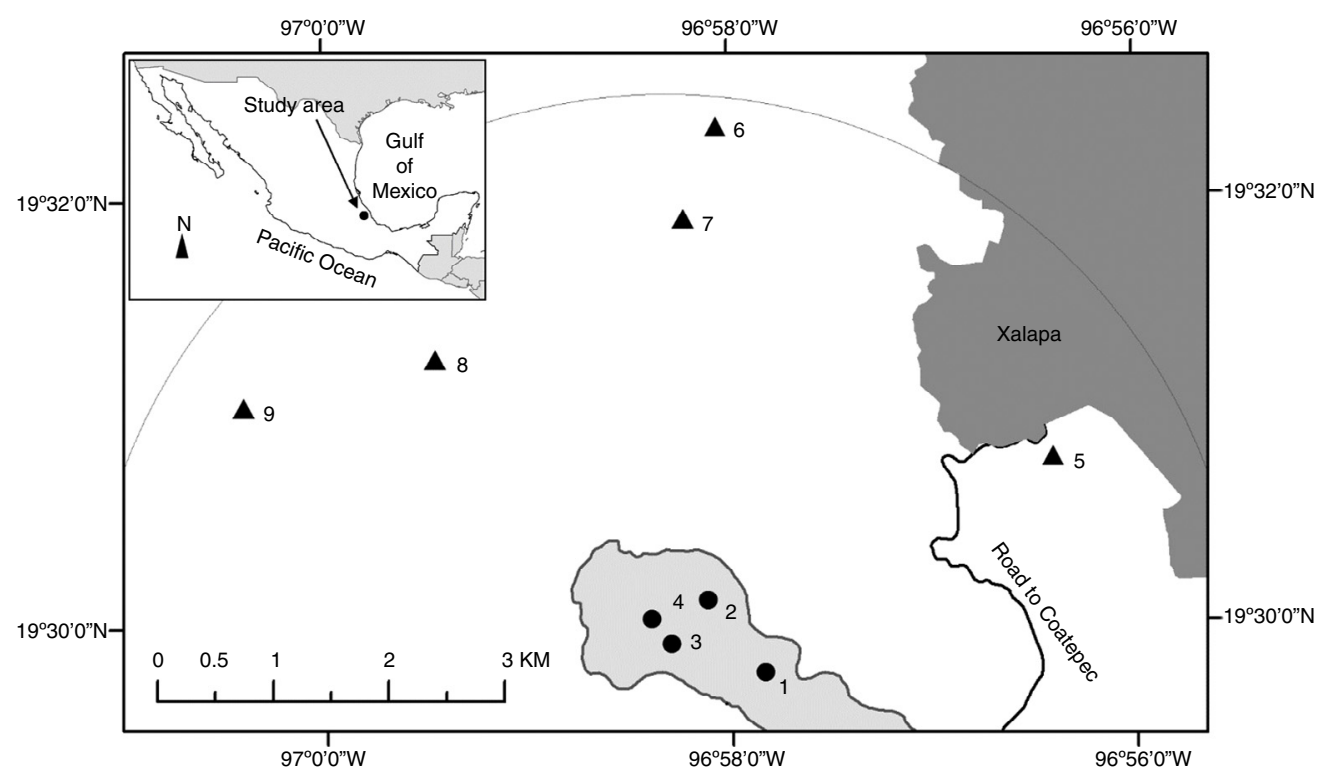

Figure 1. The inset shows the location of the study area in central Veracruz, Mexico. The shaded area where sites 1-4 are shown corresponds to limestone rock outcrop from the Miocene (Inegi, 2010, Geological-Mining maps, Coatepec E14-B37 and Xalapa E14-B27, scale 1:50,000 and Google Earth Image). Sites 5-9 are on volcanic substrate from the Quaternary. The gray part in the upper right corresponds to the urban area of Xalapa.

flat top (not including forest growing on the flanks of the hills, and (3) the conservation status of the forest was good.

From the geographic centroid of the sites on rock outcrops, we drew a semicircle $\mathrm{E}-\mathrm{W}$ to select all forest sites occurring on volcanic soil within a radius of $5 \mathrm{~km}$ (Fig. 1). Studies of forest on volcanic soils were available for comparison from published and unpublished sources; those sites were sampled by the first author and original databases were used to analyze the data (Williams-Linera, 2002; Williams-Linera et al., 2013). Hereafter, the forests on rock outcrops are referred to as FOR, and forest on volcanic soils as FOV.

In each FOR site 10 plots measuring $4 \times 25 \mathrm{~m}(0.1$ ha in total per site) were established on the relatively flat top of each hill. The plots were at least $10 \mathrm{~m}$ from the slopes to avoid steep dropoffs and edge effects. In each plot, all individuals with a diameter $\geq 5 \mathrm{~cm}$ at a height of $1.3 \mathrm{~m}$ (dbh) were counted, measured for $\mathrm{dbh}$ and species identified. Voucher specimens were collected and deposited at the XAL herbarium of the Instituto de Ecología, A.C. (INECOL).

Species richness was compared between FOR and FOV sites and among the 9 study sites after reducing the number of individuals to a common abundance level using rarefaction curves with the $S_{\text {obs }}$ Mao Tau function in EstimateS version 8.0.0 (Colwell, 2006). Morphospecies that could not be identified to family were not included in the richness analysis.

At each FOR site, mean soil depth was assessed using the rod penetration method: at 4 random points in each plot the rod was inserted into the soil until rock was encountered. One soil sample was collected with a shovel at $0-10 \mathrm{~cm}$ depth and ca. $10 \mathrm{~cm}$ diameter at the center of each plot in which vegetation was measured. The 10 samples were mixed into 2 composite samples per site. Soil samples were air dried, and $\mathrm{pH}$, organic matter content, total carbon $(\mathrm{C})$ and total nitrogen $(\mathrm{N})$ were determined in the Laboratory of Functional Ecology of the INECOL. Standard techniques were applied as set out in NOM-021-Semarnat-2000 (Semarnat, 2002).

Vegetation structure was characterized by basal area $\left(\mathrm{m}^{2} / \mathrm{ha}\right)$ and density (trees/ha). To compare the vegetation structure of the FOR sites and FOV sites we used a nested analysis of variance (Anova) with sites nested within soil type. Residuals plots were checked to detect departure from normality of errors. Statistical analyses were run in JMP software version 10.0.0 (SAS, 2012).

To identify the species characteristic of the FOR and FOV sites, 2 approaches were used, the indicator species analysis (ISA, McCune \& Grace, 2002) and a recently developed classification method (CLAM, Chazdon et al., 2011). The ISA method combines information on species abundance and occurrence between groups to identify the species characteristic of each group (i.e., those found mostly in a single group and occurring in most of the samples within that particular group). The ISA yields an indicator value and a statistical significance for this value using a Monte Carlo technique. ISA was carried out on the full matrix (4 FOR and 5 FOV sites; 62 species) to find general indicator species for the groups detected. ISA and Monte Carlo tests were run in PC-ORD software (McCune \& Grace, 2002).

CLAM is a multinomial model which uses relative abundance of species in 2 distinguishable habitats. One advantage of CLAM is that the procedure explicitly considers a threshold for rarity, meaning that species that are too rare cannot be classified, and distinguishes species that are generalists from those that demonstrate specificity to one habitat (Chazdon et al., 2011). An important parameter of the multinomial model is $K$, which refers to the cut-off point for classifying species according to their habitat. We used a $K$-level of 0.5 for simple-majority rule or liberal threshold with a $p$-level of 0.005 as suggested when the target is to classify all species, rather than a particular species (Chao \& Lin, 2011; Chazdon et al., 2011). 


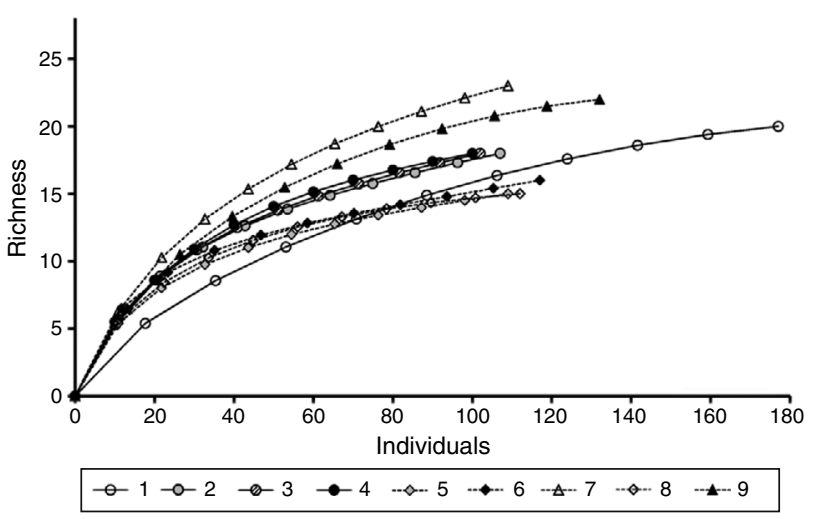

Figure 2. Rarefaction curves for number of tree species in 4 sites on limestone rock outcrop (1-4) and 5 sites on volcanic substrate (5-9) in central Veracruz, Mexico.

\section{Results}

The forests on rock substrate were well preserved and showed no indications of anthropogenic disturbance (such as woody debris indicating cut trees or firewood extraction, dung indicating the presence of livestock; Williams-Linera, 2002), except for one single trail ( $<1 \mathrm{~m}$ wide) crossing the top of the outcrop. Sites were located at the top of hills that were difficult to access and whose slopes were steep rock walls $\left(45-70^{\circ}\right.$ and $\left.90^{\circ}\right)$. These hills rise $86-160 \mathrm{~m}$ from the volcanic soil floor to the ridge (Fig. 1 and Table 1$)$. The soil is very shallow ( $<20 \mathrm{~cm}$ depth) but has a high organic matter content (Table 1).

A total of 498 individuals belonging to 34 species of 29 genera and 23 families was recorded in the FOR sites, whereas a total of 570 individuals in 42 species of 34 genera and 27 families was counted in the FOV sites (Appendix 1). Richness was similar among the study sites and varied between 15 and 23 species per site (Fig. 2). Tree species recorded in all FOR sites were Clusia guatemalensis, Cojoba arborea, Eugenia mexicana, Quercus pinnativenulosa, Turpinia insignis, Wimmeria concolor, and Zanthoxylum aff. petenense. Tree species recorded in all FOV sites were Carpinus tropicalis, Clethra macrophylla, Liquidambar styraciflua, Quercus lancifolia, and T. insignis. The best represented genus in both FOR and FOV was Quercus, and the family with the most species was Fagaceae (Appendix 1).

The indicator species analysis (ISA) identified 14 FOR species, and 7 FOV species as strong indicators of the groups ( $p<0.05$, Table 2). Using a simple majority threshold, CLAM identified 13 species as FOR specialists, 14 species as FOV specialists, 2 generalists, and 33 species too rare to classify (Table 2; Appendix 1). Consistently, both ISA and CLAM identified the same twelve species as indicators of FOR, and 7 species were identified as indicators of FOV (Table 2). There were 3 discrepancies for FOR species. ISA selected 2 of them as indicators of FOR, although CLAM considered them too rare to classify, whereas 1 species was identified by CLAM as an indicator of FOR, however, this species was not selected by ISA as an indicator. Respect to FOV species, ISA and CLAM showed less consistency, and 7 species were classed as indicators of FOV by CLAM but not by ISA (Table 2).
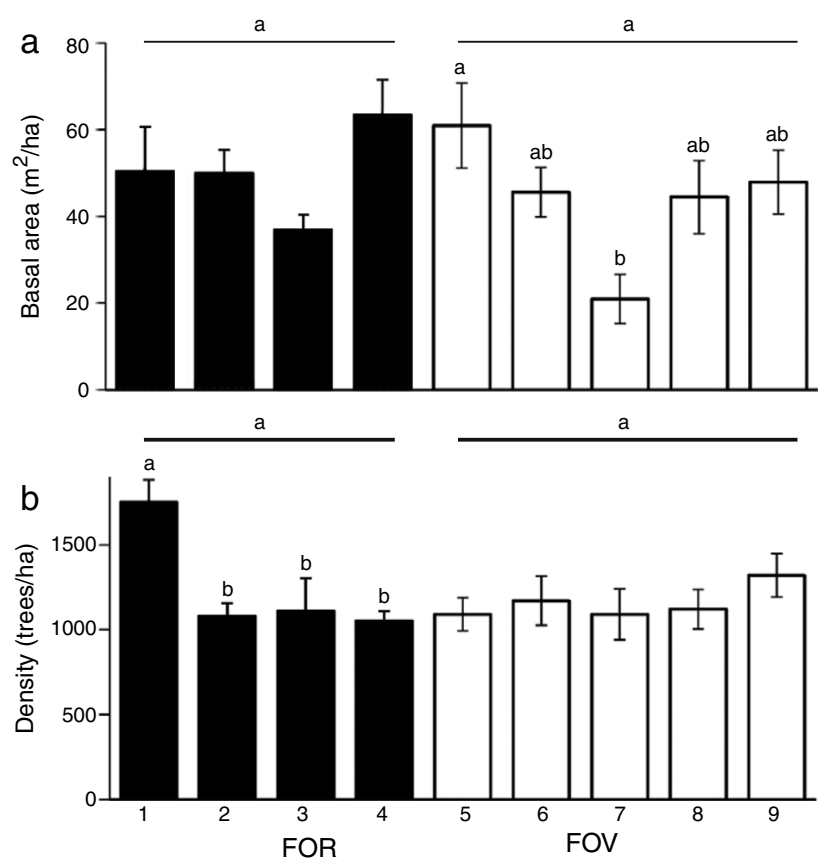

Figure 3. (a) Basal area ( $\mathrm{m}^{2} / \mathrm{ha}$ ), and (b) density (trees/ha) of trees $\geq 5 \mathrm{~cm}$ dbh of tropical montane cloud forest on rock outcrop (FOR) and volcanic soil (FOV) in central Veracruz, Mexico. Horizontal lines indicate no significant differences between FOR and FOV. Differences between sites nested within a substrate group are indicated with superscripts. Data are mean and \pm 1 SE. Sites within a group with a different letter are significantly different at alpha $=0.05$.

Vegetation structure was similar between the 2 groups of forests (FOR and FOV) for both basal area $(F=1.53, \mathrm{df}=1$, $p=0.22)$ and tree density $(F=1.10, \mathrm{df}=1, p=0.30)$. However, for sites nested within a group there were differences in basal area $(F=3.05, \mathrm{df}=7, p=0.007)$ and density $(F=3.31, \mathrm{df}=7$, $p=0.004)$. Among the FOR sites, basal area was statistically similar and varied from 36.8 to $63.4 \mathrm{~m}^{2} / \mathrm{ha}$, whereas tree density varied from 1,050 to 1,750 individuals/ha and was significantly higher at site 1 (Fig. 3a). Among the FOV sites, basal area was statistically higher at site 5 and smaller at site 7, though density was similar among sites (Fig. 3b).

Trees grouped into intervals of $5 \mathrm{~cm}$ diameter classes displayed a reverse J-shaped curve for all FOR and FOV sites (Fig. 4a and b). In this type of diameter distribution, most of the trees fall into the smallest size class: $43.7 \%$ of FOR trees and $44.3 \%$ of FOV trees fell into the 5-9 cm diameter category. Trees with intermediate diameters $(10-49 \mathrm{~cm})$ represented similar percentages at both groups of sites, and large trees $>70 \mathrm{~cm}$ were recorded at both FOR $(0.8 \%)$ and FOV $(0.7 \%)$ sites (Fig. $4 \mathrm{a}$ and b). In FOR the tree species with the biggest diameters were $Q$. pinnativenulosa, and in FOV the largest trees were L. styraciflua, Q. lancifolia and Quercus xalapensis.

\section{Discussion}

In central Veracruz, Mexico, tropical montane cloud forest is predominantly found on soils of volcanic origin and since cloud forest on limestone outcrops is scarce, FOR has been overlooked (Williams-Linera et al., 2013). This study demonstrates 
Table 1

Characteristics of tropical montane cloud forest on rock outcrop (FOR) and on volcanic soil (FOV) in central Veracruz, Mexico. Values are elevation, forest size (area), richness $\left(S_{\text {obs }}\right.$, number of tree species in $0.1 \mathrm{ha}$ ), richness after rarefaction to 100 trees (rare), soil pH, organic matter content (OM), total carbon $(\mathrm{C})$, total nitrogen $(\mathrm{N})$ and soil depth; -, missing value.

\begin{tabular}{|c|c|c|c|c|c|c|c|c|c|}
\hline & Elevation ( $\mathrm{m}$ asl) & Area (ha) & $S_{\mathrm{obs}}$ & Rare & $\mathrm{pH}$ & $\mathrm{OM}(\%)$ & $\mathrm{C}(\%)$ & $\mathrm{N}(\%)$ & Depth (m) \\
\hline \multicolumn{10}{|c|}{$\overline{F O R}$} \\
\hline 1 & 1,510 & 13.7 & 20 & 16 & 4.0 & 50.2 & 24.1 & 1.6 & 0.18 \\
\hline 2 & 1,478 & 7.4 & 18 & 17 & 3.6 & 58.7 & 33.1 & 2.6 & 0.16 \\
\hline 4 & 1,441 & 1.8 & 18 & 18 & 3.8 & 51.9 & 28.7 & 2.2 & 0.15 \\
\hline \multicolumn{10}{|c|}{ FOV } \\
\hline 7 & 1,350 & 5 & 23 & 22 & 5.5 & 14.1 & 8.2 & 0.6 & $>2$ \\
\hline 8 & 1,420 & 16 & 15 & 15 & 4.6 & 26.3 & 15.2 & 0.8 & $>2$ \\
\hline 9 & 1,630 & 12 & 22 & 20 & 3.6 & - & 8.1 & 0.6 & $>2$ \\
\hline
\end{tabular}

Table 2

Tree species selected by multinomial classification model (CLAM) and indicator species analysis (ISA) as indicators for tropical montane forest on rock outcrop (FOR) and volcanic substrate (FOV) in central Veracruz, Mexico. CLAM is based on the simple majority specialization threshold $(K=0.5, p=0.005)$. ISA values are the maximum indicator values (IV), and $p$-values $(p)$ calculated from a Monte Carlo permutation test for each species. Observed maximum indicator values range from zero (no indication) to 100 (perfect indication).

\begin{tabular}{|c|c|c|c|c|}
\hline Species & CLAM classification & ISA classification & IV & $p$ \\
\hline \multicolumn{5}{|l|}{ Forest on rock outcrop } \\
\hline Arachnothryx capitellata & Too rare to classify & FOR & 75 & 0.047 \\
\hline Cercis canadensis & FOR specialist & FOR & 75 & 0.047 \\
\hline Clusia guatemalensis & FOR specialist & FOR & 100 & 0.009 \\
\hline Cojoba arborea & FOR specialist & FOR & 100 & 0.009 \\
\hline Eugenia mexicana & FOR specialist & FOR & 83 & 0.034 \\
\hline Garrya laurifolia & FOR specialist & FOR & 75 & 0.047 \\
\hline Gymnanthes riparia & FOR specialist & FOR & 75 & 0.047 \\
\hline Oreopanax liebmannii & FOR specialist & FOR & 75 & 0.047 \\
\hline Oreopanax xalapensis & FOR specialist & Not indicator & 47 & 0.291 \\
\hline Ostrya virginiana & FOR specialist & FOR & 75 & 0.048 \\
\hline Quercus pinnativenulosa & FOR specialist & FOR & 99 & 0.018 \\
\hline Sideroxylon sp. & FOR specialist & FOR & 75 & 0.048 \\
\hline Trophis mexicana & Too rare to classify & FOR & 75 & 0.048 \\
\hline Wimmeria concolor & FOR specialist & FOR & 100 & 0.009 \\
\hline Zanthoxylum aff. petenense & FOR specialist & FOR & 90 & 0.016 \\
\hline \multicolumn{5}{|l|}{ Forest on volcanic soils } \\
\hline Carpinus tropicalis & FOV specialist & FOV & 90 & 0.035 \\
\hline Cinnaтотит effusum & FOV specialist & Not indicator & 60 & 0.171 \\
\hline Clethra macrophylla & FOV specialist & FOV & 100 & 0.009 \\
\hline Hedyosmum mexicanum & FOV specialist & Not indicator & 20 & 1 \\
\hline Liquidambar styraciflua & FOV specialist & FOV & 100 & 0.009 \\
\hline Myrsine coriacea & FOV specialist & Not indicator & 53 & 0.283 \\
\hline Quercus cortesii & FOV specialist & Not indicator & 20 & 1 \\
\hline Quercus germana & FOV specialist & Not indicator & 60 & 0.171 \\
\hline Quercus lancifolia & FOV specialist & FOV & 95 & 0.009 \\
\hline Quercus sartorii & FOV specialist & Not indicator & 55 & 0.239 \\
\hline Quercus xalapensis & FOV specialist & FOV & 80 & 0.049 \\
\hline Styrax glabrescens & FOV specialist & FOV & 80 & 0.05 \\
\hline Turpinia insignis & FOV specialist & FOV & 82 & 0.033 \\
\hline Zanthoxylum melanostictum & FOV specialist & Not indicator & 40 & 0.442 \\
\hline
\end{tabular}

that within TMCF, the tree species composition of forest communities on rock outcrops is distinct from the surrounding forest growing on volcanic soils.

Tree species richness of FOR (sites 1-4) is within the range of that reported for forests on volcanic soil (sites 6-9) (Fig. 2). Observed richness in FOR and FOV was in the range reported for other Mexican forests, although Andean and Central American forests are richer (Gentry, 1995). The fact that FOR has several tree species in common with FOV indicates that both of them can be considered as a variant of TMCF (Williams-Linera et al., 2013). At our scale of study, a high floristic similarity among the 4 FOR sites was expected given their proximity to 


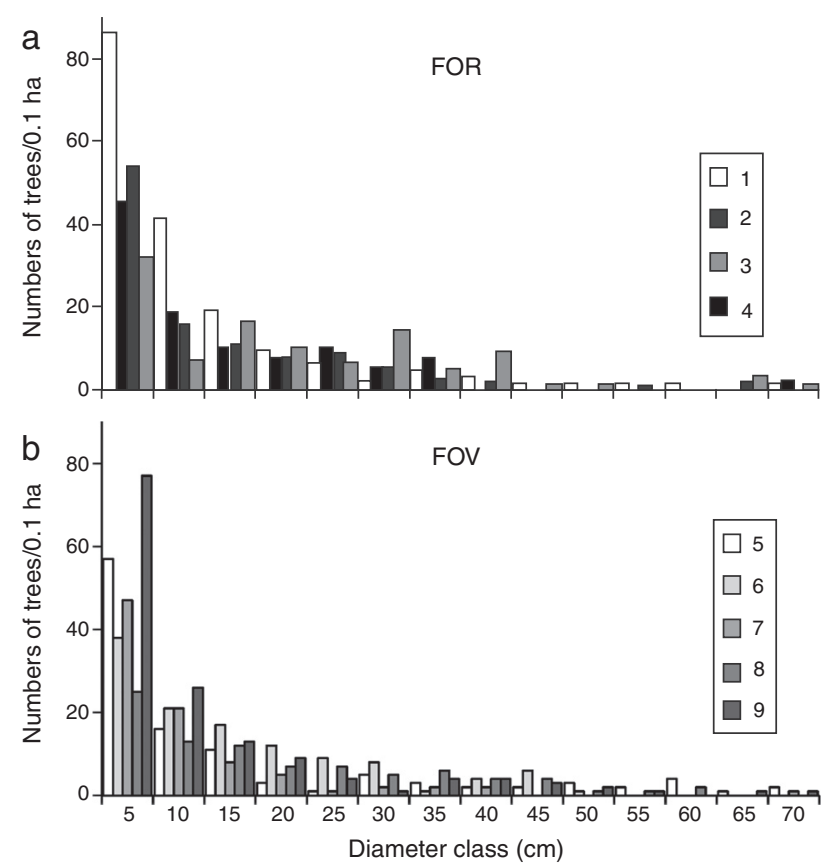

Figure 4. Distribution of stem diameters in tropical montane cloud forest on (a) rock outcrop (FOR) and (b) volcanic soil (FOV) in central Veracruz, Mexico. The lower limit of each diameter class is given.

each other. Since FOR and FOV sites are all close together, and the distinction between FOR and FOV was confirmed by the presence of some indicator species, geological substrate may be the major factor for distinctiveness. A caveat of the present study is the small number of FOR sites, however, geological substrate has been identified as one of the major factors affecting the distribution of tree species in many forest communities (Aukema et al., 2007; Cantero et al., 2014; Pérez-García et al., 2009; Rivera et al., 2000; Sawada et al., 2015; Tang et al., 2011; Wiser \& Buxton, 2009). Among Mexican tropical forests, floristic similarity has been related to geographical distances where close sites are more similar in floristic composition, but there are also nearby sites with greatly different floristic compositions, and because bioclimatic features were similar, this difference was attributed to geological substrate (Gallardo-Hernández et al., 2008; Pérez-García \& Meave, 2004; Ruiz-Jiménez, Téllez-Valdés, \& Luna-Vega, 2012).

The tree species determined to be indicators of FOR were more abundant on rock substrate, for instance, Ostrya virginiana is abundant in FOR sites but rare in FOV sites, whereas C. tropicalis is abundant in nearby forest on volcanic soils but rare in FOR sites (Williams-Linera, 2002). Also in FOR, we found species not previously recorded in surrounding FOV sites of central Veracruz but that do grow in other cloud forests in Mexico. In this category, Cercis canadensis is a FOR indicator species that has been recorded in the El Cielo Biosphere Reserve, Tamaulipas, on soil types with abundant rock outcrops (Puig \& Bracho, 1987). C. guatemalensis is another FOR indicator species whose habitat occupation patterns could be explained by ecophysiological performance, especially with respect to it photosynthetic pathway, since it is well known that some species of Clusia are CAM (Lüttge et al., 2015).
FOR sites are also distinctive because several tree species that are abundant in FOV and characterize nearby cloud forests in central Veracruz (e.g., C. macrophylla, L. styraciflua, Q. xalapensis; Ruiz-Jiménez et al., 2012; Williams-Linera et al., 2013) were not found in FOR plots. The presence of the genus Quercus stands out because of its importance; as in other cloud forests, it is the dominant genus with the highest number of species, but it is represented by different species in the 2 forest types: in FOR sites, $Q$. pinnativenulos $a$ is the indicator species while in FOV sites $Q$. germana, $Q$. lancifolia, $Q$. sartorii and $Q$. xalapensis are the indicator species.

Our forests on rock outcrops are well developed and similar in structure to nearby forest on volcanic soils in terms of basal area, density and the distribution of tree diameter classes. In Chimalapas, Mexico, vegetation structure was also similar between communities on deep soil derived from metamorphic substrate and forest on karst topography with outcroppings of rock and shallow soil (Gallardo-Hernández et al., 2008). For tropical dry forests in Mexico, the tree stratum was similar in density and basal area for forest developing on the exposed limestone bedrock and on deep soil (Pérez-García \& Meave, 2004).

Even though the FOR soil is very shallow, roots probably develop into the bedrock, and deeper root exploration may be possible due to the presence of cracks. In the Yucatán, Mexico, karstic and rocky limestone layers sustain a complex architecture of forest vegetation. In these shallow soils, many species grow roots deeper and move further down mainly through rock cracks, into cavities, and soil pockets ((Estrada-Medina, Graham, Allen, Jiménez-Osornio, \& Robles-Casolco, 2012).

The vegetation structure of FOR is characteristic of TMCF, since its basal area and density values lie within the ranges reported for TMCF worldwide (Churchill et al., 1995) as well as for other sites on volcanic soils in central Veracruz (WilliamsLinera, 2002; Williams-Linera et al., 2013). The diameter distribution where individuals with small diameter abound and large trees are rare is considered characteristic of many natural forests (Barbour, Burk, \& Pitts, 1983). The distribution observed in the FOR sites is similar to that recorded in surrounding sites on volcanic soils (Williams-Linera, 2002) and other Neotropical forests (Nadkarni, Matelson, \& Haber, 1995). In general, few trees $\geq 70 \mathrm{~cm}$ dbh were recorded in both groups of study sites, however, they were different species.

Rock outcrops are isolated islands within other types of land use such as disturbed forest, coffee plantations, old-fields, pasture and cornfields (Williams-Linera, Manson, \& Isunza, 2002). FOR sites are better preserved than FOV sites. Habitats on limestone rock outcrops and volcanic soil may differ because of differences in the degree of human influence in the past. Notably, although agriculture and coffee plantations can be found on volcanic soils, there are no crops or plantations at the top of limestone hills that have steep slopes that rise ca. $100 \mathrm{~m}$ from the floor of the surrounding land and make access difficult. Similarly, in the Dominican Republic and Puerto Rico the tops of the mogotes (haystack-shaped hilltops) have experienced less disturbance due to their poor soils and difficult access, so much of their plant diversity has remained intact, while valley and 
hillside communities appear to reflect disturbance history more strongly (Aukema et al., 2007; Rivera et al., 2000).

Our forests on outcrops, although inaccessibility resulting from the steep slopes of the hillsides, are threatened by changes in surrounding land use, mainly from urbanization and clearing to make way for pastures. Forests on rock outcrops have shallow soils with very high organic matter content and are considered organic soils. Places where cloud forests grow on organic soils have been related to deep ground fires with severe effects, as occurred in 1998 in Los Chimalapas, Mexico (Asbjornsen, Velázquez-Rosas, García-Soriano, \& Gallardo-Hernández, 2005). These fires are not frequent, but have occurred at very long time intervals in the past (Wård, Malmer, \& Asbjornsen, 2010), and in a climate change scenario this represents another potential threat to cloud forest. Another major threat related to habitat fragility and destruction is posed by the complete destruction of forest communities to convert the hills into quarries for the extraction of building materials.

The limestone outcrops on the TMCF landscape provide an exceptional opportunity for future research to understand how the forest community develops and recruitment takes place on shallow soils, and whether some tree species may have specificity to one type of habitat. Our results partially support the working hypothesis since, in terms of basal area and density, the vegetation structure of forest growing on limestone substrate is similar to that of forest on volcanic soil. However, there are notable differences between FOR and FOV sites in their indicator tree species. We conclude that cloud forest on limestone substrate is of particular interest in biodiversity conservation due to its different assemblage of species compared to that of the surrounding FOV sites, and the contribution of FOR sites to the maintenance of high beta diversity in the region.

\section{Acknowledgments}

To Don Moisés Villa Martínez for his willingness to guide us in the rock outcrops. We thank Claudia Gallardo Hernández for assistance with species identification, and Víctor Vázquez and Alberto García for help during fieldwork. This study was funded by the Instituto de Ecología, A.C. (Project 2003010145).

Appendix 1. Tree species and family of individuals $\geq 5$ $\mathrm{cm}$ dbh recorded in tropical montane cloud forest sites on limestone outcrop (FOR sites, 1 to 4) and volcanic soil (FOV sites, 5 to 9) in central Veracruz, Mexico. The numbers represent species abundance in 0.1 ha. Classification is based on CLAM analysis using a simple majority approach $(K=0.5$ and $p=0.005)$. Species were classified as FOR specialist, FOV specialist, generalist or too rare to classify.

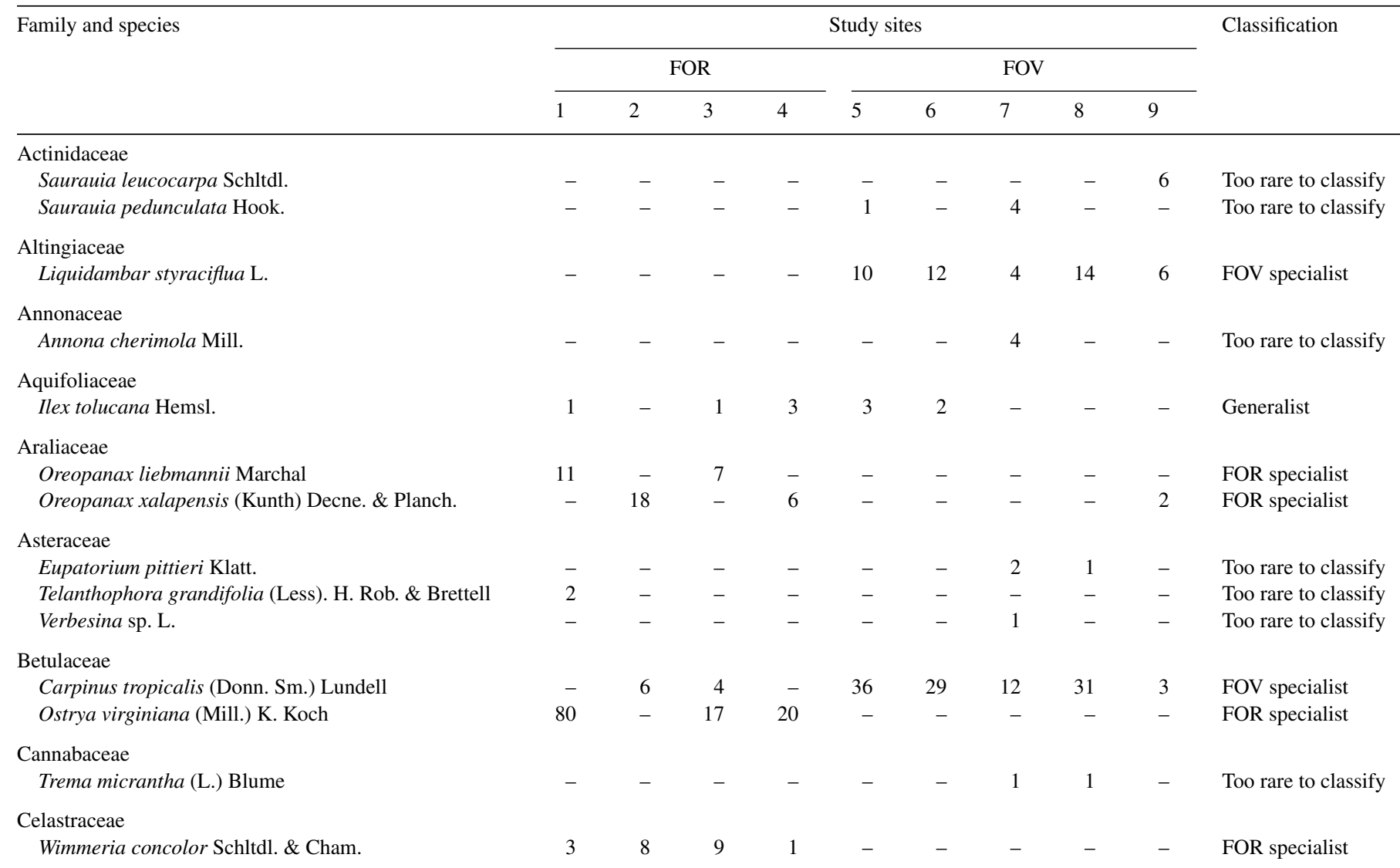




\section{Appendix 1 (Continued)}

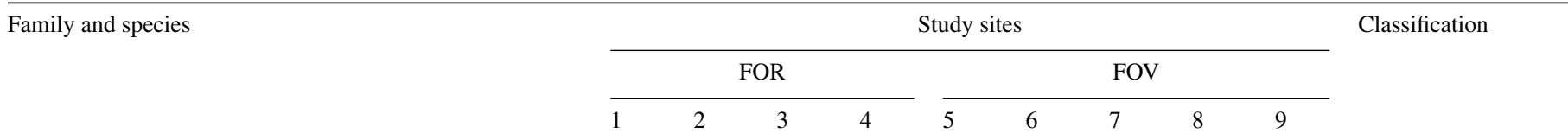

Chloranthaceae

Hedyosmum mexicanum C. Cordem.

Clethraceae

Clethra macrophylla M. Martens \& Galeotti

Clusiaceae

Clusia guatemalensis Hemsl.

Cornaceae

Cornus excelsa Kunth

Euphorbiaceae

Alchornea latifolia Sw.

Bernardia interrupta (Schltdl.) Müll. Arg.

Cnidosculus sp. Pohl

Gymnanthes riparia (Schltdl.) Klotzsch

Fabaceae

Cercis canadensis L.

Cojoba arborea (L.) Britton \& Rose

Leucaena leucocephala (Lam.) de Wit

Lonchocarpus orizabensis Lundell

Vachellia pennatula (Schltdl. \& Cham.) Seigler \&

Ebinger

Fagaceae

Quercus cortesii Liebm.

Quercus germana Schltdl. \& Cham.

Quercus lancifolia Schltdl. \& Cham.

Quercus pinnativenulosa C.H. Mull.

Quercus sartorii Liebm.

Quercus xalapensis Bonpl.

Garryaceae

Garrya laurifolia Hartw. ex Benth.

Lauraceae

Cinnamomum effusum (Meisn.) Kosterm.

Ocotea psychotrioides Kunth

Persea americana Mill.

Malvaceae

Heliocarpus donnellsmithii Rose

Melastomataceae

Conostegia arborea Steud.

Miconia glaberrima (Schltdl.) Naudin

Moraceae

Trophis mexicana (Liebm.) Bureau

Myrtaceae

Eugenia mexicana Steud.

Eugenia xalapensis (Kunth) DC.

Primulaceae

Myrsine coriacea (Sw.) R. Br. ex Roem. \& Schult.

Rhamnaceae

Rhamnus sp. L.

Rosaceae

Prunus rhamnoides Koehne

Rubiaceae

Arachnothryx capitellata (Hemsl.) Borhidi

Deppea grandiflora Schltdl. 


\section{Appendix 1 (Continued)}

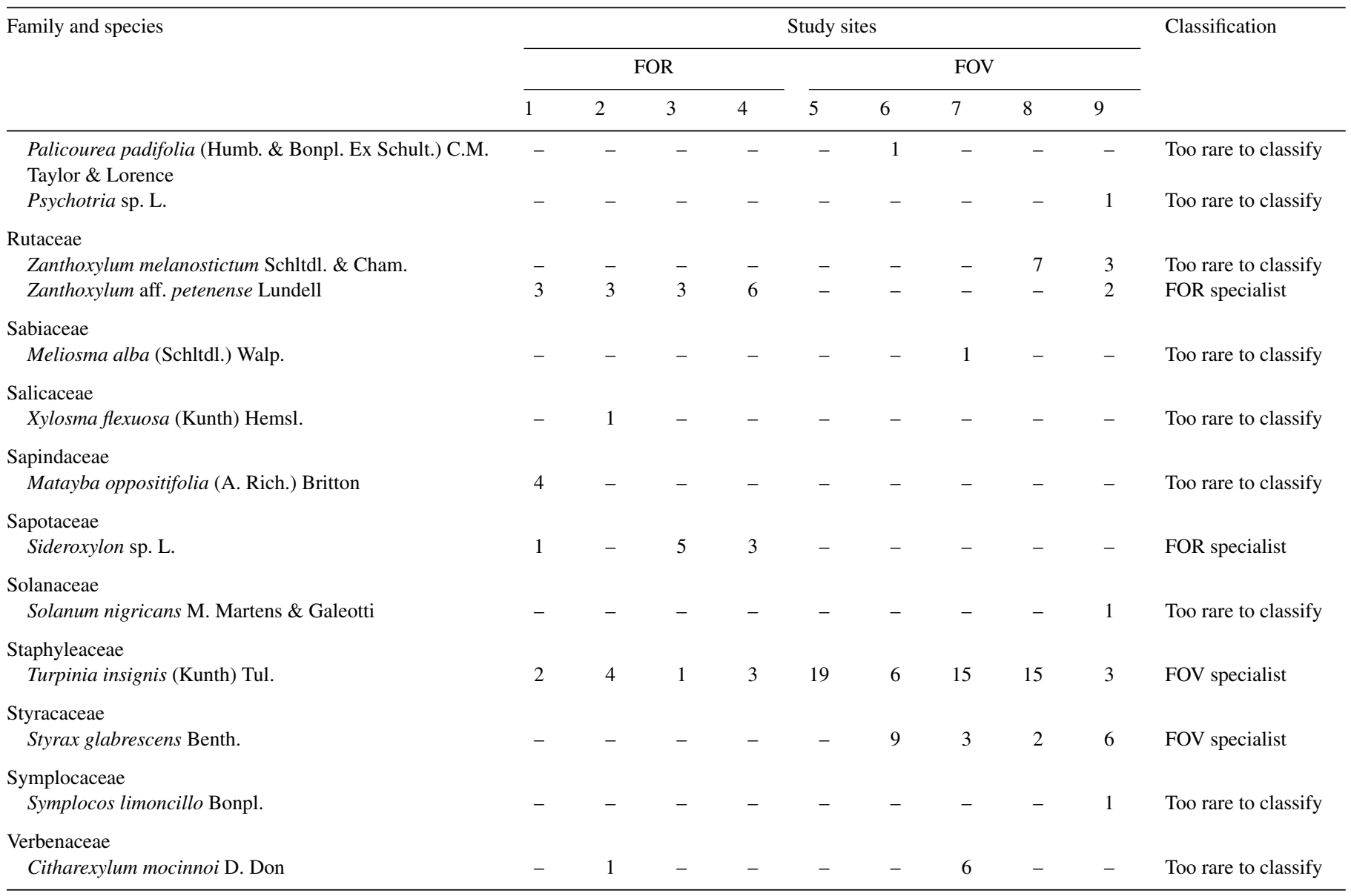

\section{References}

Asbjornsen, H., Velázquez-Rosas, N., García-Soriano, R., \& GallardoHernández, C. (2005). Deep ground fires cause massive above-and below-ground biomass losses in tropical montane cloud forests in Oaxaca, Mexico. Journal of Tropical Ecology, 21, 427-434.

Aukema, J. E., Carlo, T. A., \& Collazo, J. A. (2007). Landscape assessment of tree communities in the northern karst region of Puerto Rico. Plant Ecology, $189,101-115$.

Barbour, M. G., Burk, J. H., \& Pitts, W. D. (1983). Terrestrial plant ecology. Menlo Park, CA, USA: The Benjamin/Cummings Publishing Company.

Brewer, S. W., Rejmánek, M., Webb, M. A. H., \& Fine, P. V. A. (2003). Relationship of phytogeography and diversity of tropical tree species with limestone topography in southern Belize. Journal of Biogeography, 30, 1669-1688.

Bruijnzeel, L. A., Kappelle, M., Mulligan, M., \& Scatena, F. N. (2010). Tropical montane cloud forests: State of knowledge and sustainability perspectives in a changing world. In L. A. Bruijnzeel, F. N. Scatena, \& L. S. Hamilton (Eds.), Tropical montane cloud forests: science for conservation and management (pp. 691-740). Cambridge, MA: Cambridge University Press.

Cantero, J. J., Sfragulla, J. A., Núñez, C., Mulko, J., Bonalumi, A. A., Amuchastegui, A., et al. (2014). Vegetación de afloramientos carbonáticos de montañas del centro de Argentina. Boletín de la Sociedad Argentina de Botánica, 49, 559-580.

Chao, A., \& Lin, S. Y. (2011). Program CLAM (Classification Method). Program and user's guide at http://purl.oclc.org/clam

Chazdon, R. L., Chao, A., Colwell, R. K., Lin, S. Y., Norden, N., Letcher, S. G., et al. (2011). A novel statistical method for classifying habitat generalists and specialists. Ecology, 92, 1332-1343.
Colwell, R. K. (2006). EstimateS: Statistical estimation of species richness and shared species from samples. Version 8. Persistent URL: purl.oclc.org/estimates.

Churchill, S. P., Balslev, H., Forero, E., \& Luteyn, J. L. (Eds.). (1995). Biodiversity and conservation of neotropical montane forests. New York: The New York Botanical Garden.

Estrada-Medina, H., Graham, R. C., Allen, M. F., Jiménez-Osornio, J. J., \& Robles-Casolco, S. (2012). The importance of limestone bedrock and dissolution karst features on tree root distribution in northern Yucatán, Mexico. Plant and Soil, 362, 37-50

Gallardo-Hernández, C., Velázquez, N. R., \& Asbjornsen, H. (2008). Composición florística y estructura arbórea de dos comunidades de bosque mesófilo de montaña afectadas por los incendios de 1998, en Los Chimalapas, Oaxaca, México. In L. R. Sánchez-Velásquez, J. Galindo-González, \& F. DíazFleischer (Eds.), Ecología, manejo y conservación de los ecosistemas de montaña en México (pp. 167-183). Mexico, D.F.: Mundi Prensa.

Gentry, A. H. (1995). Patterns of diversity and floristic composition in Neotropical montane forest. In S. P. Churchill, H. Balslev, E. Forero, \& J. L. Luteyn (Eds.), Biodiversity and conservation of Neotropical montane forests (pp. 103-126). New York: The New York Botanical Garden.

Inegi (Instituto Nacional de Estadística y Geografía). (2010). Carta GeológicaMinera, Coatepec E14-B37, Xalapa E14-B26. Pachuca: Servicio Geológico Mexicano.

Lüttge, U., Scarano, F. R., de Mattos, E. A., Franco, A. C., Broetto, F., Dias, A. T. C., et al. (2015). Does ecophysiological behaviour explain habitat occupation of sympatric Clusia species in a Brazilian Atlantic rainforest? Trees, 29, 1973-1988.

McCune, B., \& Grace, J. B. (2002). Analysis of ecological communities. Gleneden Beach, Oregon: MjM Software Design. 
Muñoz-Villers, L. E., Holwerda, F., Gómez-Cárdenas, M., Equihua, M., Asbjornsen, H., Bruijnzeel, L. A., et al. (2012). Water balances of old-growth and regenerating montane cloud forests in central Veracruz, Mexico. Journal of Hydrology, 462-463, 53-66.

Nadkarni, N., Matelson, T. J., \& Haber, W. A. (1995). Structural characteristics and floristic composition of a Neotropical cloud forest, Monteverde, Costa Rica. Journal of Tropical Ecology, 11, 481-495.

Pérez-García, E. A., \& Meave, J. A. (2004). Heterogeneity of xerophytic vegetation of limestone outcrops in a tropical deciduous forest region in southern Mexico. Plant Ecology, 175, 147-163.

Pérez-García, E. A., Sevilha, A. C., Meave, J. A., \& Scariot, A. (2009). Floristic differentiation in limestone outcrops of southern Mexico and central Brazil: a beta diversity approach. Boletín de la Sociedad Botánica de México, 84, $45-58$.

Puig, H., \& Bracho, R. (1987). El bosque mesófilo de montaña de Tamaulipas. México, D.F.: Instituto de Ecología, A.C.

Rivera, L. W., Zimmerman, J. K., \& Aide, T. M. (2000). Forest recovery in abandoned agricultural lands in a karst region of the Dominican Republic. Plant Ecology, 148, 115-125.

Rodríguez, S. R., Morales-Barrera, W., Layer, P., \& González-Mercado, E. (2010). A quaternary monogenetic volcanic field in the Xalapa region, eastern Trans-Mexican volcanic belt: geology, distribution and morphology of the volcanic vents. Journal of Volcanology and Geothermal Research, 197, 149-166.

Rossignol, J. P. (1987). Los estudios morfoedafológicos en el área XalapaCoatepec Veracruz. In D. Geissert, \& J. P. Rossignol (Eds.), La morfoedafología en la ordenación de los paisajes rurales (pp. 23-35). Xalapa, Veracruz: INIREB-ORSTOM.

Ruiz-Jiménez, C. A., Téllez-Valdés, O., \& Luna-Vega, I. (2012). Clasificación de los bosques mesófilos de montaña de México: afinidades de la flora. Revista Mexicana de Biodiversidad, 83, 1110-1144.

Rzedowski, J. (1996). Análisis preliminar de la flora vascular de los bosques mesófilos de montaña de México. Acta Botanica Mexicana, 35, 25-44.

Sánchez-Ramos, G., \& Dirzo, R. (2014). El bosque mesófilo de montaña: un ecosistema prioritario amenazado. In M. Gual-Díaz, \&
A. Rendón-Correa (Eds.), Bosques mesófilos de montaña de México: diversidad, ecología y manejo (pp. 109-139). México, D.F.: Comisión Nacional para el Conocimiento y Uso de la Biodiversidad.

SAS (Statistical Analysis System). (2012). JMP User's Guide. Cary, NC: SAS Institute.

Sawada, Y., Aiba, S., Takyu, M., Repin, R., Nais, J., \& Kitayama, K. (2015) Community dynamics over 14 years along gradients of geological substrate and topography in tropical montane forests on Mount Kinabalu, Borneo. Journal of Tropical Ecology, 31, 117-128.

Semarnat (Secretaría de Medio Ambiente y Recursos Naturales). (2002). Norma Oficial Mexicana NOM-021-RECNAT 2000, Especificaciones de fertilidad, salinidad y clasificación de suelos. Estudios, muestreo y análisis. Diario Oficial 31, December 2000, Mexico.

Tang, J. W., Lü, X. T., Yin, J. X., \& Qi, J. F. (2011). Diversity, composition and physical structure of tropical forest over limestone in Xishuangbanna, South-West China. Journal of Tropical Forest Science, 23, 425-433.

Wård, Y., Malmer, A., \& Asbjornsen, H. (2010). Historical ${ }^{14} \mathrm{C}$ evidence of fire in tropical montane cloud forest in the Chimalapas region of Oaxaca southern Mexico. In L. A. Bruijnzeel, F. N. Scatena, \& L. S. Hamilton (Eds.), Tropical montane cloud forests: science for conservation and management (pp. 575-578). Cambridge, MA: Cambridge University Press.

Williams-Linera, G. (2002). Tree species richness complementarity, disturbance and fragmentation in a Mexican tropical montane cloud forest. Biodiversity and Conservation, 11, 1825-1843.

Williams-Linera, G., Manson, R. H., \& Isunza, E. V. (2002). La fragmentación del bosque mesófilo de montaña y patrones de uso del suelo en la región oeste de Xalapa, Veracruz, México. Madera y Bosques, 8, 69-85.

Williams-Linera, G., Toledo-Garibaldi, M., \& Gallardo-Hernández, C. (2013). How heterogeneous are the cloud forest communities in the mountains of central Veracruz, Mexico. Plant Ecology, 214, 685-701.

Wiser, S. K., \& Buxton, R. P. (2009). Montane outcrop vegetation of Banks Peninsula, South Island, New Zealand. New Zealand Journal of Ecology, 33, 164-176. 